\title{
Unexpectedly fast photochemistry in wintertime haze: Consequences for pollution mitigation strategies.
}

Keding $\mathrm{Lu}^{1 *}$, Hendrik Fuchs ${ }^{2}$, Andreas Hofzumahaus ${ }^{2}$, Zhaofeng Tan ${ }^{1, \mathrm{a}}$, Haichao Wang ${ }^{1}$, Lin Zhang ${ }^{3}$, Sebastian H. Schmitt ${ }^{2}$, Franz Rohrer ${ }^{2}$, Birger Bohn ${ }^{2}$, Sebastian Broch $^{2}$, Huabin Dong ${ }^{1}$, Georgios I. Gkatzelis ${ }^{2}$, Thorsten Hohaus ${ }^{2}$, Frank Holland ${ }^{2}$, Xin $\mathrm{Li}^{1}$, Ying Liu ${ }^{1}$, Yuhan Liu ${ }^{1}$, Xuefei Ma ${ }^{1}$, Anna Novelli ${ }^{2}$, Patrick Schlag ${ }^{2, b}$, Min Shao ${ }^{1}$, Yusheng $\mathrm{Wu}^{1, \mathrm{c}}$, Zhijun $\mathrm{Wu}^{1}$, Limin Zeng ${ }^{1}$, Min $\mathrm{Hu}^{1}$, Astrid Kiendler-Scharr ${ }^{2}$, Andreas Wahner $^{2}$, \& Yuanhang Zhang ${ }^{1,4,5}$ *

1 State Key Joint Laboratory of Environmental Simulation and Pollution Control, College of Environmental Sciences and Engineering, Peking University, Beijing, China.

2 IEK-8: Troposphere, Forschungszentrum Jülich, Jülich, Germany.

${ }^{3}$ Laboratory for Climate and Ocean-Atmosphere Studies, Department of Atmospheric and Oceanic Sciences, School of Physics, Peking University, Beijing 100871, China.

${ }^{4}$ CAS Center for Excellence in Regional Atmospheric Environment, Chinese Academy of Science, Xiamen, China.

${ }^{5}$ Beijing Innovation Center for Engineering Sciences and Advanced Technology, Peking University, Beijing, China.

${ }^{a}$ now at: IEK-8: Troposphere, Forschungszentrum Jülich, Jülich, Germany.

${ }^{b}$ now at: Institute of Physics, University Sao Paulo, Sao Paulo, Brazil.

${ }^{c}$ now at: Department of Physics, University of Helsinki, Helsinki, Finland. 


\section{Contents for Methods}

Description of the instrument for $\mathrm{OH}$ and $\mathrm{HO}_{2}$ concentration measurements ...............S3

Description of the instrument for total $\mathrm{OH}$ reactivity measurements ............................S4

Description of the instrument for $\mathrm{N}_{2} \mathrm{O}_{5}$ concentration measurements .........................S4

Description of the instrument for HONO concentration measurements .........................S5

Description of the instrument for HCHO concentration measurements ........................S5

Description of the instrument for PAN concentration measurements............................S6

Description of the instrument for VOC concentration measurements ...........................S6

Description of the instruments for aerosol chemical composition measurements ..........S7

Description of the instruments for determining photolysis frequencies .......................S9

Description of the instruments for measuring meteorological parameters ....................S9

\section{Contents for Figures}

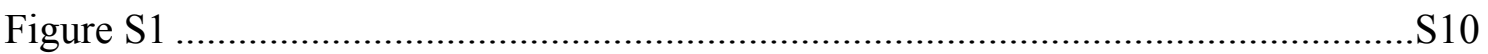

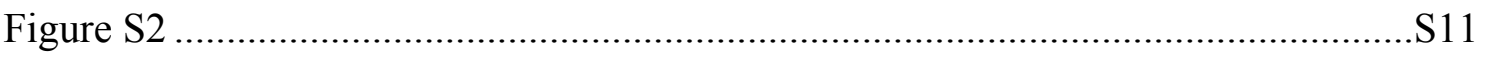

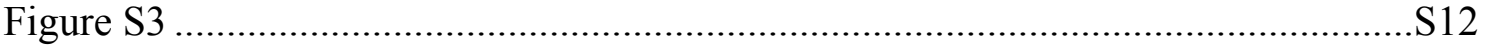

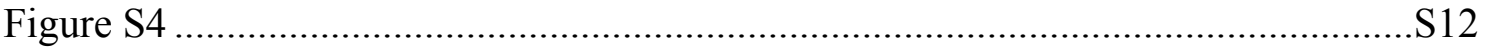

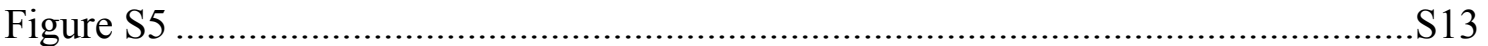

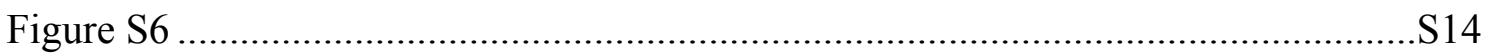

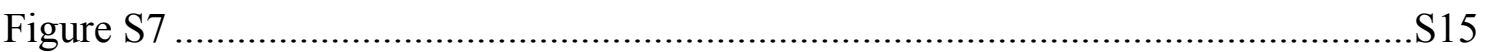

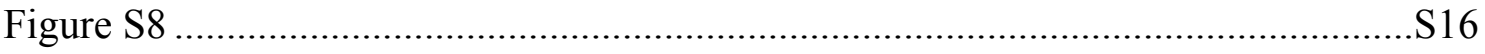

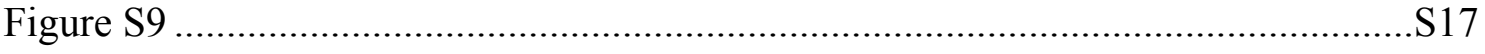

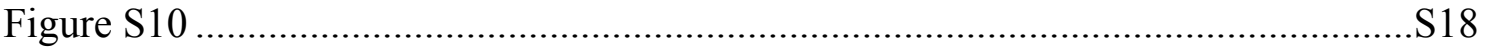

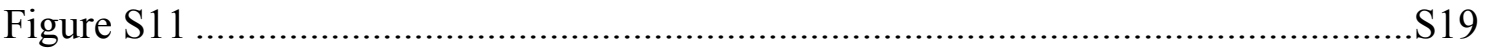

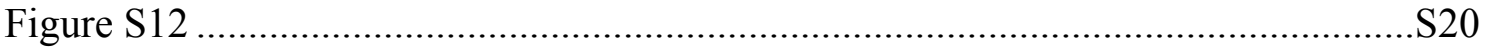

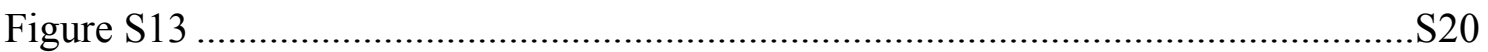




\section{Supplementary Methods}

\section{Description of the instrument for $\mathrm{OH}$ and $\mathrm{HO}_{2}$ concentration measurements}

$\mathrm{OH}$ and $\mathrm{HO}_{2}$ radical concentrations were measured by the laser-induced fluorescence (LIF) instrument previously used in the 2014 summer campaign in Wangdu south of Beijing (Tan et al., 2017). Separate detection cells for $\mathrm{OH}$ and $\mathrm{HO}_{2}$ were operated at a pressure of $4 \mathrm{hPa}$. Approximately $20 \mathrm{~mW}$ of $308 \mathrm{~nm}$ laser radiation generated by a pulsed, frequency-doubled tunable dye laser was sequentially passed through the two cells. Ambient air was sampled into each cell through $0.4 \mathrm{~mm}$ nozzles with flow rates of 1 slpm $($ slpm $=$ standard litres per minute). The $\mathrm{OH}$ measurement is based on the detection of the $\mathrm{OH}$ resonance fluorescence induced by the incident $308 \mathrm{~nm}$ laser radiation. As recently reported (e.g. Mao et al., 2012), OH detection by LIF in a lowpressure cell can potentially suffer from interferences by internally produced $\mathrm{OH}$, which can be quantified by chemical modulation (Feiner et al., 2016). This concept has been implemented in the instrument previously (Fuchs et al, 2011; Fuchs et al., 2016) and was used in the present campaign on several days (January $9^{\text {th }}, 13^{\text {th }}, 25^{\text {th }}$ and March $1^{\text {st }}$ ). No significant $\mathrm{OH}$ interference signals were found for the conditions of this winter campaign (Tan et al., 2018). $\mathrm{HO}_{2}$ measurements were achieved by chemical conversion of $\mathrm{HO}_{2}$ to $\mathrm{OH}$ in the reaction with added $\mathrm{NO}$. The converted $\mathrm{OH}$ was then detected by LIF. When high concentrations of NO are added for best possible conversion efficiencies, part of the atmospheric $\mathrm{RO}_{2}$ radicals from long-chain alkanes, alkenes and aromatics can also be converted to $\mathrm{OH}$, thereby producing a significant interference (Fuchs et al., 2011). In the present campaign, this interference was avoided by adding only small concentrations of $\mathrm{NO}$. The $\mathrm{HO}_{2}$ cell was operated alternatingly at $\mathrm{HO}_{2}$ conversion efficiencies of $5 \%$ for 1 minute and $25 \%$ for 5 minutes, showing no difference in the $\mathrm{HO}_{2}$ concentrations obtained for the two conversion efficiencies. This result suggests that interferences from $\mathrm{RO}_{2}$ were negligible. The detection limits (signalto-noise ratio of 2) for $30 \mathrm{~s}$ time resolution were $0.8 \times 10^{6} \mathrm{~cm}^{-3}$ and $0.2 \times 10^{8} \mathrm{~cm}^{-3}$ for $\mathrm{OH}$ and $\mathrm{HO}_{2}$, respectively. The accuracies of the radical concentrations were calculated from the reproducibility of the calibrated sensitivities and the inherent systematic uncertainties of the calibration method, yielding $2 \sigma$ accuracies of $28 \%$ and $34 \%$ for $\mathrm{OH}$ and $\mathrm{HO}_{2}$, respectively. 


\section{Description of the instrument for total $\mathrm{OH}$ reactivity measurements}

The total $\mathrm{OH}$ reactivity $\left(k_{\mathrm{OH}}\right)$ of air is equivalent to the inverse atmospheric $\mathrm{OH}$ lifetime. In this study, $k_{\mathrm{OH}}$ was measured with an instrument based on laser photolysis - laser induced fluorescence (LP-LIF) (Hofzumahaus et al., 2009; Lou et al., 2010; Fuchs et al., $2017 \mathrm{a}, \mathrm{b})$. Ambient air was passed at a flow rate of $19 \mathrm{~L} \mathrm{~min}^{-1}$ through a flow tube and part of the air was drawn into an $\mathrm{OH}$ fluorescence detection cell. A large concentration of $\mathrm{OH}$ radicals (about $10^{9}$ molecules $\mathrm{cm}^{-3}$ ) was produced within a few nanoseconds in the flow tube by flash photolysis of $\mathrm{O}_{3}$ with subsequent reaction of $\mathrm{O}\left({ }^{1} \mathrm{D}\right)$ atoms with water vapor $\left(\mathrm{O}_{3}+h v(266 \mathrm{~nm}) \rightarrow \mathrm{O}_{2}+\mathrm{O}^{1} \mathrm{D}, \mathrm{O}^{1} \mathrm{D}+\mathrm{H}_{2} \mathrm{O} \rightarrow 2 \mathrm{OH}\right)$. The $266 \mathrm{~nm}$ radiation was provided by a quadrupled Nd:YAG laser pulse, which was operated at a low repetition rate of $1 \mathrm{~Hz}$. Pseudo first-order decays of $\mathrm{OH}$ were recorded between to photolysis laser shots by LIF. Atmospheric $k_{\mathrm{OH}}$ was determined from the lifetime of the exponential decay and corrected for $\mathrm{OH}$ wall loss having a value of $(3.0 \pm 0.3) \mathrm{s}^{-1}$ in the flow tube. The time resolution of the $k_{\mathrm{OH}}$ measurements was 90 seconds with a limit of detection of $0.3 \mathrm{~s}^{-1}$. The resulting accuracy of $k_{\mathrm{OH}}$ is $(5-10) \% \pm 0.7 \mathrm{~s}^{-1}$ at $\mathrm{NO}$ mixing ratios below 20 ppbv. At higher ambient NO concentrations, which were observed from time to time during the campaign, the $\mathrm{OH}$ decays in the flow tube show deviations from a mono-exponential behavior, caused by $\mathrm{OH}$ recycling from the reaction of $\mathrm{HO}_{2}$ with NO. In these cases, a bi-exponential fit allows the determination of $k_{\mathrm{OH}}$ with an overall accuracy of $20 \% \pm 0.7 \mathrm{~s}^{-1}$ (Lou et al., 2010).

The $\mathrm{OH}$ reactivity of VOCs (total VOC reactivity) was estimated as the difference of the measured total $\mathrm{OH}$ reactivity and the calculated reactivity of measured inorganic compounds $\left(\mathrm{CO}, \mathrm{NO}, \mathrm{NO}_{2}\right)$. The $\mathrm{SO}_{2}$ contribution to $k_{\mathrm{OH}}$ was not significant in this campaign.

\section{Description of the instrument for $\mathrm{N}_{2} \mathrm{O}_{5}$ concentration measurements}

$\mathrm{N}_{2} \mathrm{O}_{5}$ was measured by thermal decomposition - cavity enhanced absorption spectroscopy (CEAS) (Wang et al., 2017a). In the custom-built instrument, $\mathrm{N}_{2} \mathrm{O}_{5}$ is converted to $\mathrm{NO}_{3}$ at a temperature of $120{ }^{\circ} \mathrm{C}$ and then detected as $\mathrm{NO}_{3}$ at its UV-VIS absorption maximum around $662 \mathrm{~nm}$ at $80{ }^{\circ} \mathrm{C}$. The particle filter at the beginning of the inlet tube was exchanged once per hour under polluted conditions. The limit of 
detection (LOD) was estimated to be $2.7 \mathrm{pptv}(1 \sigma)$ with an uncertainty of $19 \%$ for a time resolution of $60 \mathrm{~s}$.

\section{Description of the instrument for HONO concentration measurements}

HONO was measured by two customized, in-house designed instruments from Peking University (PKU) and Forschungszentrum Juelich (FZJ) using the LOPAP (long path absorption photometer) technique (Li et al., 2014; Liu et al., 2016). Both instruments utilize a sampling unit consisting of two stripping coils in series. HONO reacts with 60 $\mathrm{mM}$ sulfanilamide in $1 \mathrm{mM} \mathrm{HCl}$ as adsorption solution and is converted to an azo dye with an aqueous solution of $0.8 \mathrm{mM} \mathrm{N}$-(1-naphthyl) ethylenediamine dihydrochloride (NEDA). The formed azo dye is photometrically measured in a Liquid Core Waveguide. For both LOPAP instruments, the time resolution was 5 minutes, detection limits were 10 pptv, measurement uncertainties were $12 \%$, and sampling efficiencies were larger than $99.9 \%$. The measurements of the two LOPAP instruments were averaged, yielding a combined HONO dataset with an uncertainty of $\pm 20 \%$ (Tan et al., 2018).

\section{Description of the instrument for HCHO concentration measurements}

HCHO was measured by Hantzsch Fluorimetry with a commercial instrument (AL4021, Aerolaser GmbH, Germany). The sensitivity of the instrument was calibrated using liquid HCHO standards. The standards were added to the stripping coil instead of the stripping solution while HCHO-free air was passed through the coil. The calibration was performed at three concentration levels of liquid HCHO standards. The concentrations corresponded to gas-phase mixing ratios of 2 ppbv, 10 ppbv, and 35 ppbv. HCHO-free air was generated by passing the sampled air through a catalyst (Hopkalit, Draeger) at room temperature. The HCHO-free air was also used to determine the background signal of the instrument. Calibrations for the sensitivity of the instrument, as well as for the measured flow rates were performed in the beginning and in the end of the campaign. Determined sensitivities agreed within 2\%. The accuracy of the $\mathrm{HCHO}$ measurements was around 5\% mainly due to the uncertainty of the calibration. The $1 \sigma$ precision derived from the $\mathrm{HCHO}$-free air measurements was around $25 \mathrm{pptv}$ at a time resolution of $2 \mathrm{~min}$. 


\section{Description of the instrument for PAN concentration measurements}

Peroxyacetyl nitrate (PAN) was measured by an on-line monitoring system using low temperature gas chromatography (GC) - electron capture detection (ECD) technology. Automatic calibrations were routinely achieved through photosynthesis of a PAN standard from acetaldehyde followed by the further reaction with NO (Huang et al., 2017). The lower detection limit of this instrument was 50 pptv and the time resolution of measurements was 5 min.

\section{Description of the instrument for $\mathrm{HNO}_{3}, \mathrm{NO}_{3}{ }^{-}$and $\mathrm{NH}_{3}$ concentration measurements}

Nitric acid $\left(\mathrm{HNO}_{3}\right)$, particulate nitrate $\left(\mathrm{NO}_{3}^{-}\right)$and Ammonia $\left(\mathrm{NH}_{3}\right)$ were measured by a Gas and Aerosol Collector coupled with two Ion chromatographic systems (GAC-IC) (Dong et al., 2012). A wet denuder system was used in the instrument with pure water as its absorption solution. Ambient air was sampled with a flowrate of $16.7 \mathrm{~L} / \mathrm{min}$ through a $3 / 8$ " Teflon tube and absorbed by pure water. A cyclone filter is installed in front of the $3 / 8$ " Teflon tube and the aerosol cut off size is $2.5 \mu \mathrm{m}$. Thereafter, the solution was automatically transferred through a filter, injected into the cation IC and measured. The lower detection limit of this instrument was $65 \mathrm{ppt}, 0.034 \mu \mathrm{g} / \mathrm{m}^{3}$ and 30 pptv for $\mathrm{HNO}_{3}, \mathrm{NO}_{3}{ }^{-}$and $\mathrm{NH}_{3}$, respectively and the time resolution was $30 \mathrm{~min}$. The measurement of $\mathrm{HNO}_{3}$ concentrations may be negatively biased the due to the uptake at the inlet walls for the part of the inlet outside the heated lab while positively biased due to the decomposition of $\mathrm{NH}_{4} \mathrm{NO}_{3}$ for the part of inlet inside the heated lab. Similar bias will also take place for the measurement of $\mathrm{NH}_{3}$. The measurement accuracy for $\mathrm{HNO}_{3}$ and $\mathrm{NH}_{3}$ were estimated to be $30 \%$ due to the intercomparsion of $\mathrm{NH}_{3}$ performed in the previous campaigns and the measurement accuracy for $\mathrm{NO}_{3}{ }^{-}$was estimated to be $10 \%$.

\section{Description of the instrument for VOC concentration measurements}

The online measurements of ambient VOC concentrations $\left(\mathrm{C}_{2}-\mathrm{C}_{12}\right.$ hydrocarbons $)$ were done by a gas chromatography system coupled with a flame ionization and mass spectrometer detection (GC-MS/FID). Measurements had a time resolution of one hour during the campaign. VOCs were pre-concentrated in an ultralow temperature, cryogenfree pre-concentration device. Detailed analytical methods and quality-assurance 
quality-control (QA-QC) procedures for this system have been described elsewhere (Yuan et al., 2012). Detection limits for various compounds were in the range of $(0.005-0.070)$ ppbv with an uncertainty of measurements was $(10-15) \%$.

\section{Description of the instruments for aerosol surface area concentration measurements}

Particle number size distributions (PNSD) were measured by a scanning mobility particle sizer (SMPS) (Long-DMA3081 + CPC3775) and a Nano-SMPS (NanoDMA3085 + UCPC3776). The multiple charge correction, condensation particle counter (CPC) counting efficiency, and particle loss correction were applied to the measurements. An aerodynamic particle sizer (APS, TSI model 3321, TSI Inc., St. Paul, $\mathrm{MN}$, USA) measured the particle-number size distribution between $500 \mathrm{~nm}$ and $10 \mathrm{~mm}$ (aerodynamic diameter). The APS results were transformed from aerodynamic to Stokes diameters using a particle density of $1.5 \mathrm{~g} \mathrm{~cm}^{-3}$. The dry-state aerosol surface area was calculated based on the dry-state particle number and geometric diameter in each size bin $(<2.5 \mu \mathrm{m})$ with a time resolution of $5 \mathrm{~min}$.

Dry-state aerosol surface area was calculated based on PNSD, and corrected to ambient (wet) particle aerosol surface area accounting for particle hygroscopic growth. The growth factor was estimated by the ISORROPIA-II aerosol thermodynamics model (Clegg et al., 1998). The model input included water-soluble ions, along with simultaneously measured $\mathrm{RH}$ and $\mathrm{T}$. The aerosol solutions were assumed to be metastable. Firstly, the model calculated the mass of aerosol liquid water content (ALWC), then determined the growth factor by taking the cube root of the ratio of the wet to the dry aerosol mass. The overall accuracy for the deduced ambient particle aerosol surface area was estimated to be $30 \%$.

\section{Description of the instruments for aerosol chemical composition measurements}

Aerosol chemical composition $\left(<\mathrm{PM}_{1.0}\right)$ was measured using an Aerodyne High Resolution Time-of-Flight Aerosol Mass Spectrometer (HR-ToF-AMS; short: AMS) (DeCarlo et al., 2006). Only specific parameters and settings for the described set-up will be given here. The AMS is capable of measuring the non-refractory fraction of ambient aerosol particles $\left(\mathrm{NR}-\mathrm{PM}_{1}\right)$ including organics (Org), ammonium $\left(\mathrm{NH}_{4}^{+}\right)$, 
nitrate $\left(\mathrm{NO}_{3}^{-}\right)$, sulfate $\left(\mathrm{SO}_{4}{ }^{2-}\right)$ and chloride $\left(\mathrm{Cl}^{-}\right)$in a size range of $60-600 \mathrm{~nm}$ (Liu et al., 1995). The AMS used for this study was modified by a quadrupole filter between the ionization region and the mass spectrometer. Fragmentation patterns of $\mathrm{NH}_{4}{ }^{+}, \mathrm{NO}_{3}{ }^{-}$ and $\mathrm{SO}_{4}{ }^{2-}$ indicated that the quadrupole did not influence the transmission in the investigated $\mathrm{m} / \mathrm{z}$ range $(12-250 \mathrm{amu})$. Therefore, standard AMS data evaluation procedures could be applied. The detection limits for each species were determined from measuring particle free air for 14 times throughout the full campaign. The detection limit for organic (Org.), $\mathrm{NH}_{4}{ }^{+}, \mathrm{NO}_{3}{ }^{-}, \mathrm{SO}_{4}{ }^{2-}$, and $\mathrm{Cl}^{-}$mass concentrations were $0.424 \mu \mathrm{g} / \mathrm{m}^{3}, 0.005 \mu \mathrm{g} / \mathrm{m}^{3}, 0.029 \mu \mathrm{g} / \mathrm{m}^{3}, 0.011 \mu \mathrm{g} / \mathrm{m}^{3}, 0.023 \mu \mathrm{g} / \mathrm{m}^{3}$, respectively.

The AMS was calibrated regularly (approximately every 7-10 days; except during the 19 days of the Spring Festival break) using size selected $(350 \mathrm{~nm})$ and dried $\mathrm{NH}_{4} \mathrm{NO}_{3}$ particles and a CPC (TSI model 3786) as a reference (Jayne et al., 2000; Jimenez et al, 2003). From all calibrations, an average ionization efficiency (i.e. total response factor including transfer efficiency of the ToF-MS) of $1.61 \pm 0.26 \times 10^{-08}$ was obtained by this procedure and was subsequently used for the determination of aerosol mass concentrations. Compound specific relative ionization efficiencies (RIE) for $\mathrm{NH}_{4}{ }^{+}$and $\mathrm{SO}_{4}{ }^{2-}$ were determined during the standard calibration procedure. The RIE of Org, $\mathrm{NH}_{4}{ }^{+}$, $\mathrm{NO}_{3}{ }^{-}, \mathrm{SO}_{4}{ }^{2-}, \mathrm{Cl}^{-}$were $1.4,2.71 \pm 0.12,1.1,1.54 \pm 0.04,1.3$, respectively.

To correct for non-unity collection efficiencies of the AMS, a composition dependent correction factor was applied (Middlebrook et al., 2012). A comparison to $\mathrm{PM}_{1}$ concentration values measured by a collocated scanning mobility particle sizer (SMPS) system showed that the total mass measured by the AMS on average accounts for $84 \%$ and $73 \%$ of the mass measured by the SMPS assuming an effective aerosol density of $1.4 \mathrm{~g} \mathrm{~cm}^{-3}$ and $1.6 \mathrm{~g} \mathrm{~cm}^{-3}$, respectively. The density is expected to be within this range based the fact that the aerosol mass consists of at least $50 \% \mathrm{NH}_{4} \mathrm{NO}_{3}$ and organics (both $1.4 \mathrm{~g} \mathrm{~cm}^{-3}$ ) and up to $50 \%\left(\mathrm{NH}_{4}\right)_{2} \mathrm{SO}_{4}\left(1.77 \mathrm{~g} \mathrm{~cm}^{-3}\right)$ and $\mathrm{NH}_{4} \mathrm{HSO}_{4}\left(1.78 \mathrm{~g} \mathrm{~cm}^{-3}\right)$. Taking into account that, (i) the AMS can only detect the non-refractory part of the aerosol and (ii) slight differences in the size ranges are covered by AMS and SMPS, the agreement of $\mathrm{PM}_{1}$ masses measured by the two instruments is reasonable and assures that the AMS data can be quantitatively interpreted.

The AMS was located inside the building and sampled through a 0.18 ' inner diameter (ID) stainless steel inlet line ( $2 \mathrm{~m}$ length) that was further connected to a $0.255^{\prime}$ ID 
stainless steel line coated with Silcoinert ${ }^{\circledR}$ (7.3m length). Including the $0.06 \mathrm{~L} \mathrm{~min}^{-1}$ withdrawal of the AMS, the total sampling flow was $1.82 \mathrm{~L} \mathrm{~min}^{-1}$ and the residence time of the sampling air in the inlet line was approximately $10 \mathrm{~s}$. While the outside temperature was varying from $-19.2{ }^{\circ} \mathrm{C}$ to $19.0{ }^{\circ} \mathrm{C}$, the temperature at the AMS inlet was rather constant with temperatures between $20.0^{\circ} \mathrm{C}$ and $26.5^{\circ} \mathrm{C}$. Directly in front of the AMS the inlet flow was dried using a Nafion drier $(\mathrm{RH}<6 \%)$ and subsequently the flow was split to a CPC (TSI 3786, flow rate: $0.60 \mathrm{~L} \mathrm{~min}^{-1}$ ). In front of the Nafion drier an optical particle counter (OPC; Grimm model 1.129) took a subsample of $1.16 \mathrm{~L} \mathrm{~min}^{-1}$.

\section{Description of the instruments for determining photolysis frequencies}

Photolysis frequencies were calculated from spectral actinic flux densities measured with a spectroradiometer (Meteorologie Consult). The instrument employed a quartz receiver, a monolithic single monochromator and a photodiode-array. The setup was calibrated with a PTB-traceable irradiance standard before and after the campaign (Hofzumahaus et al., 2009). The accuracy of the actinic flux measurements was estimated $10 \%$ in the UV range at solar zenith angles smaller than $80^{\circ}$, which is the estimated accuracy for $\mathrm{J}\left(\mathrm{O}^{1} \mathrm{D}\right)$ and $\mathrm{J}\left(\mathrm{NO}_{2}\right)$ as well.

\section{Description of the instruments for measuring meteorological parameters}

Meteorological parameters including wind speed, wind direction, relative humidity $(\mathrm{RH})$, temperature $(\mathrm{T})$ and pressure $(\mathrm{p})$ were measured with a commercial Met One Meteorological Sensors \& Systems. Wind speed and wind direction were measured by Met One 014A and 024A, respectively. RH and T were measured by a multi-parameter sensor system (Met One 083E). The air pressure was measured by Met One 092. 


\section{Supplementary Figures}

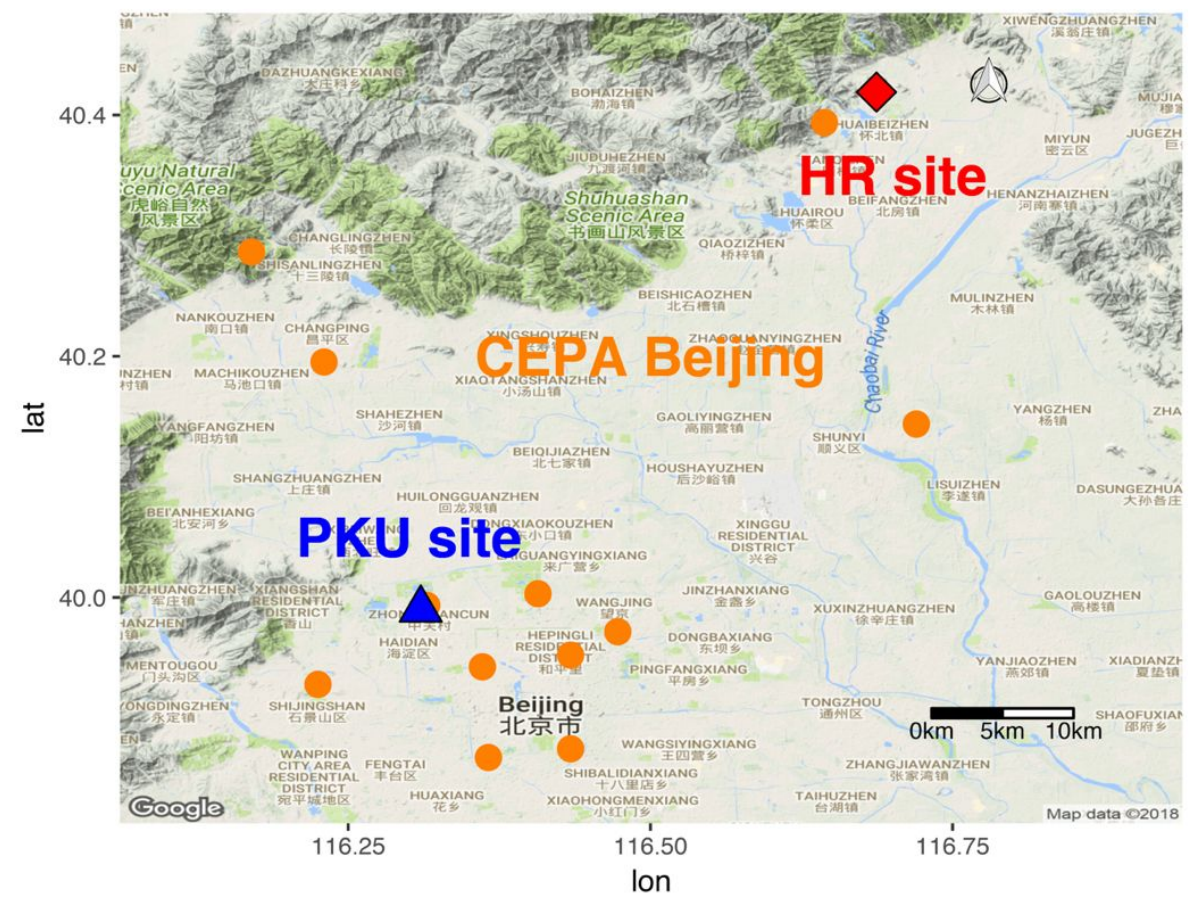

Figure S1. Locations of the Huairou (HR) site, the Peking University (PKU) site and the monitoring sites of the Chinese Environmental Protection Agency (CEPA) in Beijing. 


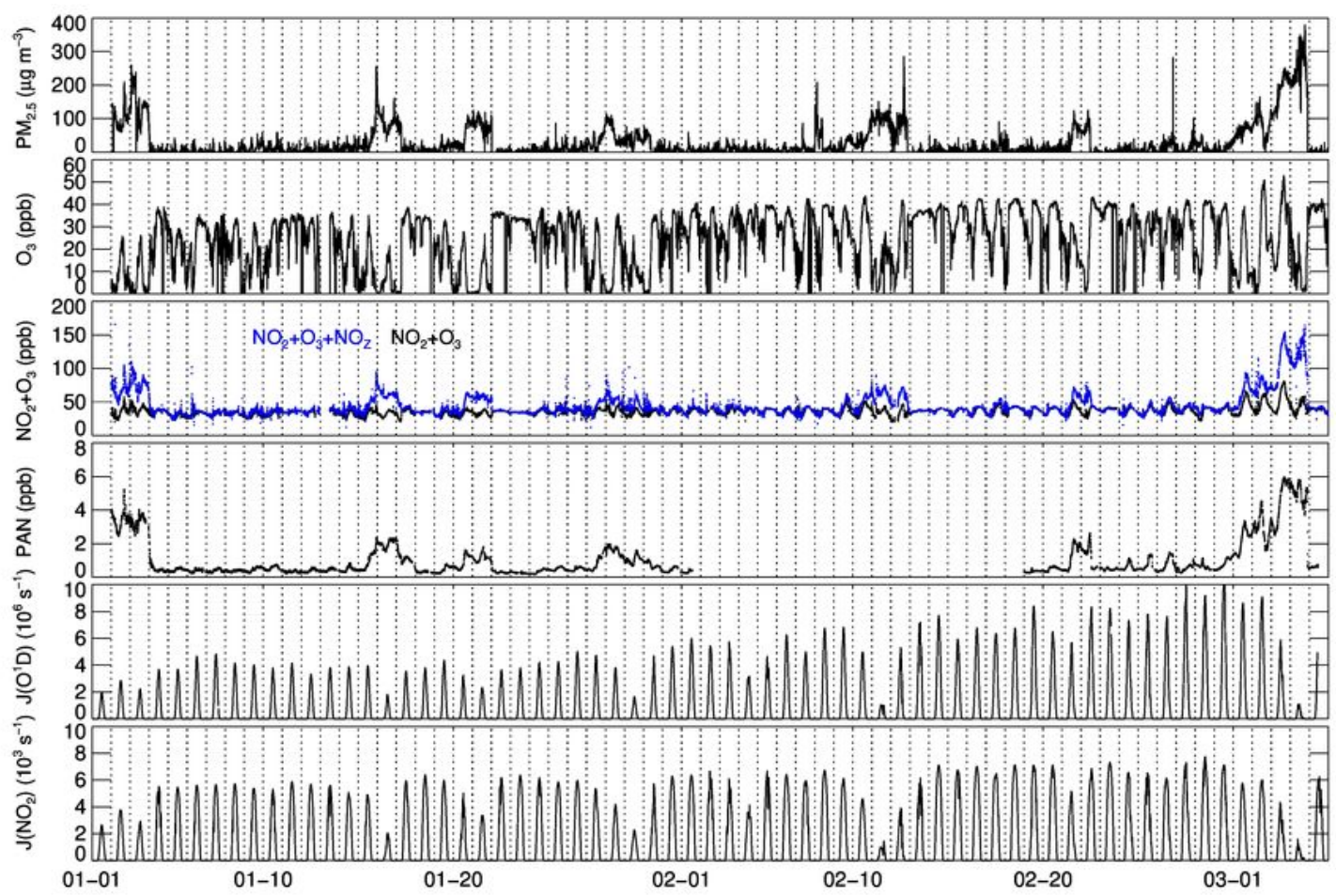

Figure S2. Time series of $\mathrm{PM}_{2.5}, \mathrm{O}_{3}, \mathrm{O}_{3}+\mathrm{NO}_{2}, \mathrm{O}_{3}+\mathrm{NO}_{2}+\mathrm{NOz}, \mathrm{PAN}, \mathrm{j}\left(\mathrm{O}^{1} \mathrm{D}\right)$ and $\mathrm{j}\left(\mathrm{NO}_{2}\right)$ during the campaign. Several 1-2 day long pollution episodes were observed indicated by $\mathrm{PM}_{2.5}$ mass concentrations between 100 and $200 \mu \mathrm{g} \mathrm{m}^{-3}$. The strong pollution episode from February $29^{\text {th }}$ to March $5^{\text {th }}$ showed an even higher increase of $\mathrm{PM}_{2.5}$ reaching values of up to $360 \mu \mathrm{g} \mathrm{m}^{-3}$. The ozone mixing ratio was approximately 40 ppbv in clean episodes and showed frequently short-term drops to lower concentrations due to its reaction with emitted $\mathrm{NO}$, which forms $\mathrm{NO}_{2}$. The concentration of $\mathrm{Ox}\left(\mathrm{O}_{3}+\right.$ $\mathrm{NO}_{2}$ ) was remarkably stable. During the pollution episodes, however, Ox and other gaseous pollutants (NOz, and PAN) became photochemically enhanced and increased concurrently with $\mathrm{PM}_{2.5}$, even though the photolysis frequencies $\mathrm{j}\left(\mathrm{O}^{1} \mathrm{D}\right)$ and $\mathrm{j}\left(\mathrm{NO}_{2}\right)$ decreased considerably. 


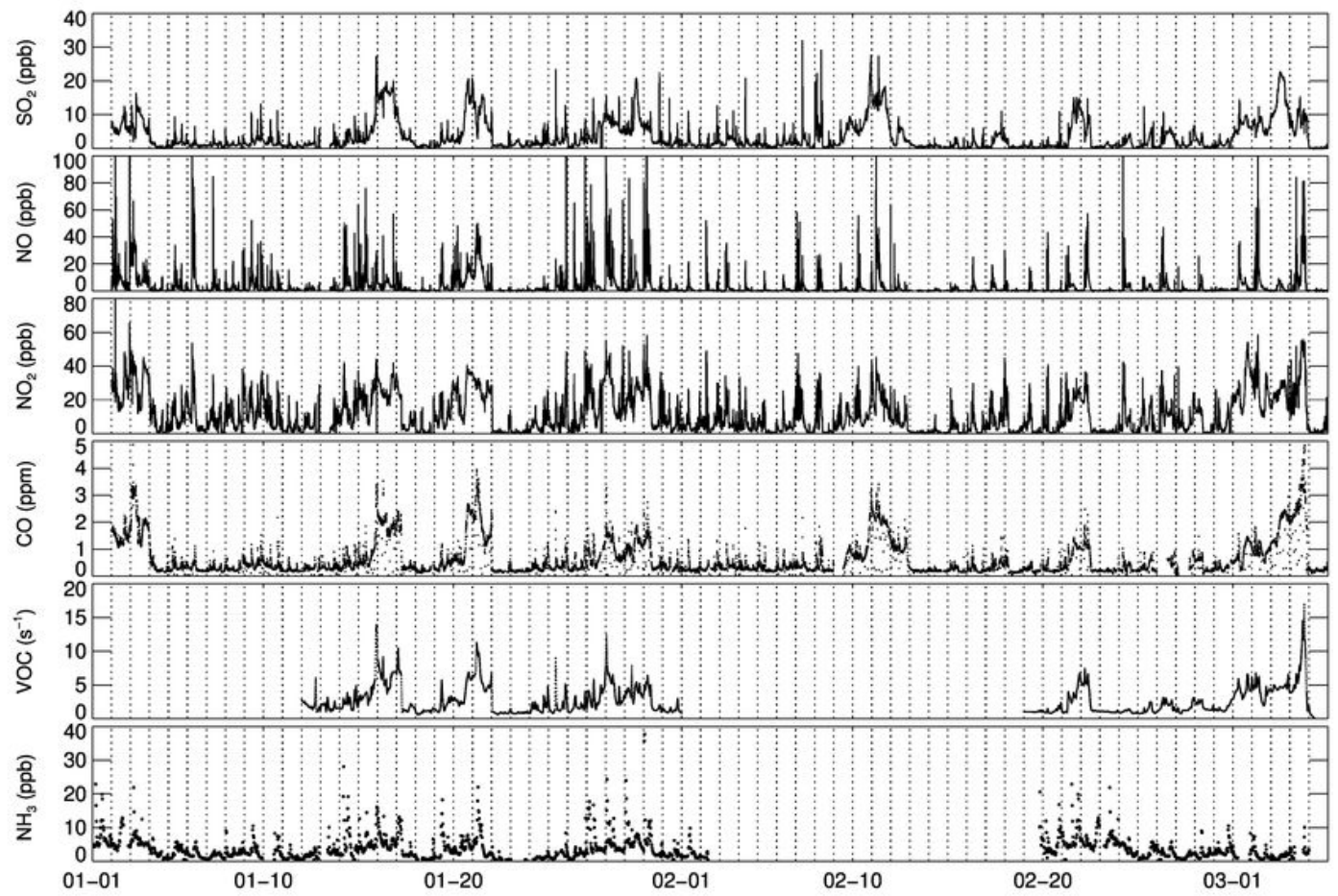

Figure S3. Time series of $\mathrm{SO}_{2}, \mathrm{NO}, \mathrm{NO}_{2}, \mathrm{CO}$ and $\mathrm{NH}_{3}$ concentrations and of the $\mathrm{OH}$ reactivity from VOCs during the campaign.

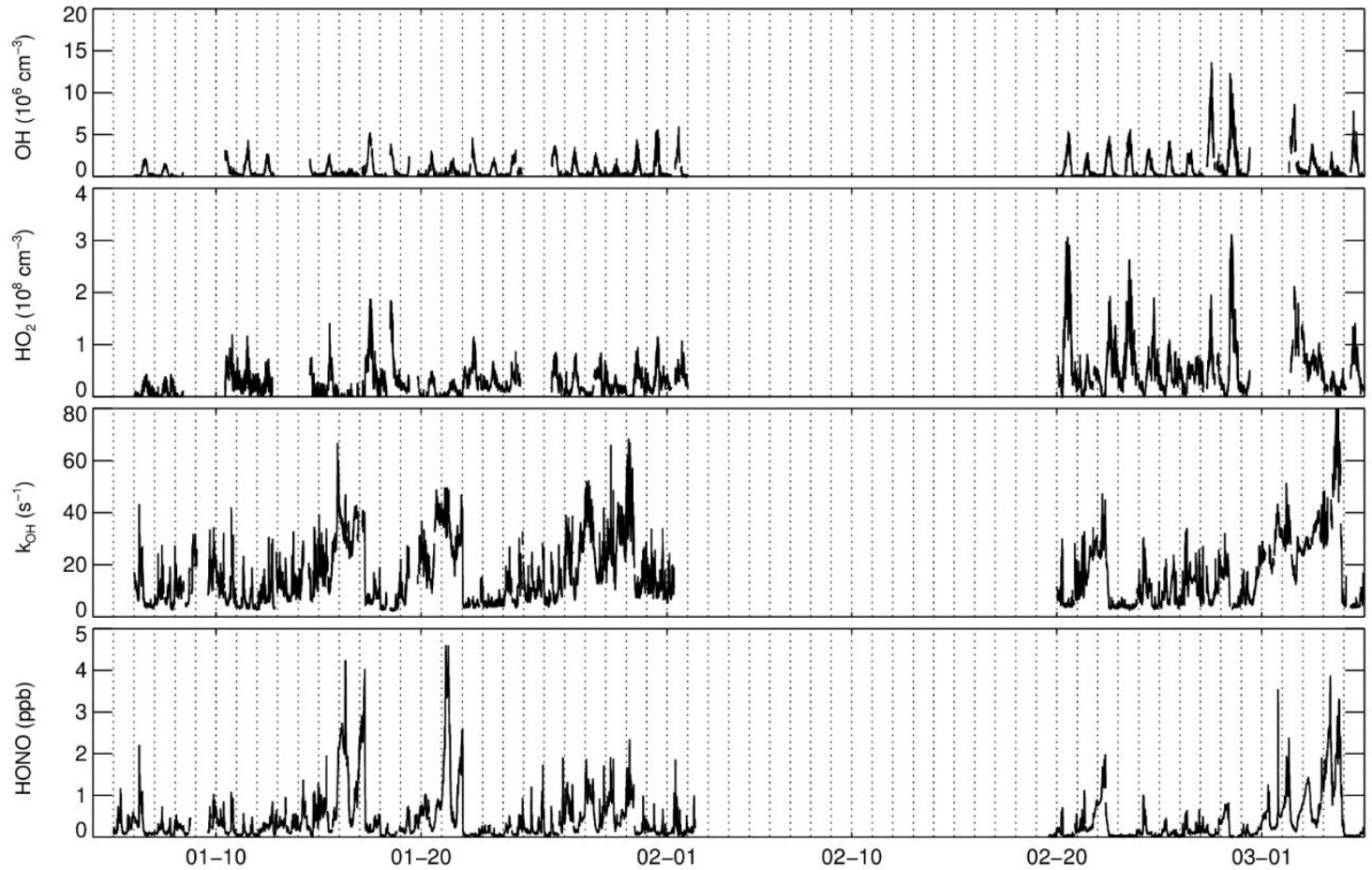

Figure S4. Time series of $\mathrm{OH}, \mathrm{HO}_{2}, \mathrm{k}_{\mathrm{OH}}$ and $\mathrm{HONO}$ concentrations during the campaign. 


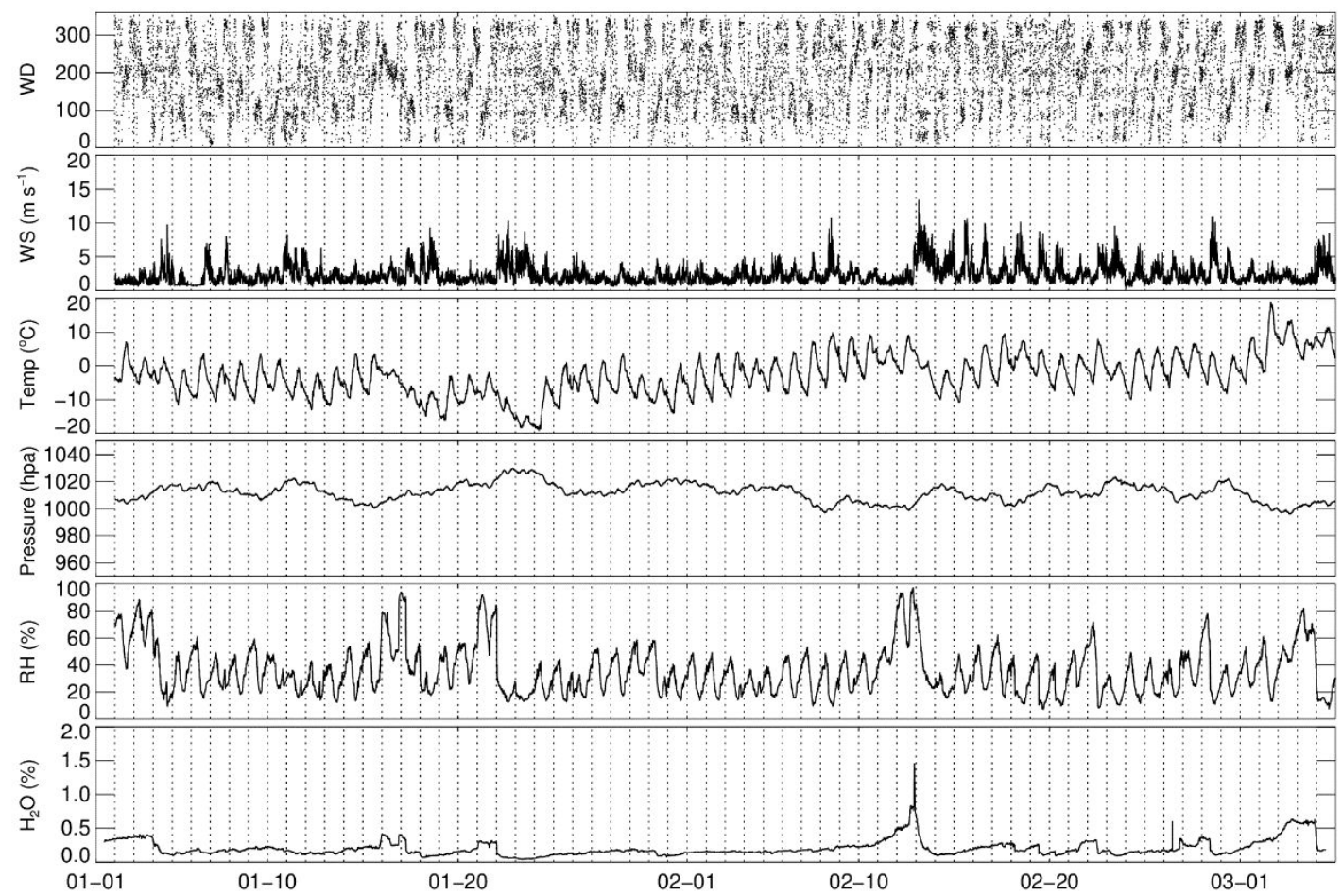

Figure S5. Time series of the wind direction (WD), wind speed (WS), temperature (Temp), pressure, relative humidity $(\mathrm{RH})$ and water vapor mixing ratios $\left(\mathrm{H}_{2} \mathrm{O}\right)$ during the campaign. 


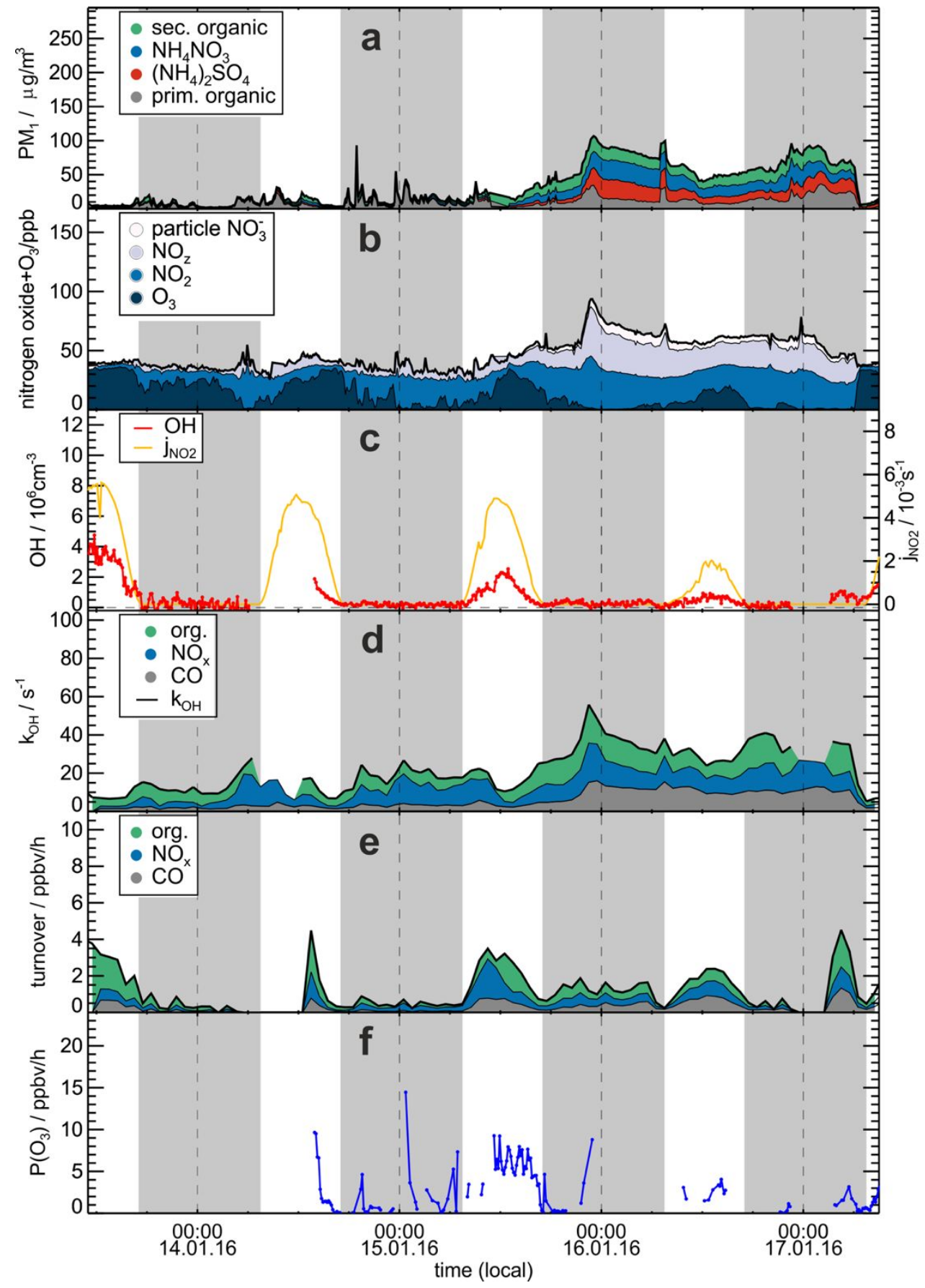

Figure S6. Atmospheric measurements at Huairou from January $13^{\text {th }}$ to January $17^{\text {th }}$ 2016: Aerosol $\left(\mathrm{PM}_{1}\right)$ chemical composition (a), ozone and nitrogen oxide species resulting from ozone oxidation of $\mathrm{NO}$ emissions $\left(\mathrm{NO}_{2}\right.$, higher gaseous oxidation products $\mathrm{NOz}$, particulate nitrate $\mathrm{NO}_{3}^{-}$) (b), $\mathrm{OH}$ concentrations and solar UV-A intensity represented as $\mathrm{NO}_{2}$ photolysis frequency $\left(\mathrm{j}_{\mathrm{NO} 2}\right)(\mathrm{c})$, partitioning of the total $\mathrm{OH}$ reactivity $\left(\mathrm{k}_{\mathrm{OH}}\right)$ to contribution from $\mathrm{CO}, \mathrm{NO}_{\mathrm{X}}$ and organics $(\mathrm{d}), \mathrm{OH}$ removal rate $\left(\mathrm{k}_{\mathrm{OH}} \times[\mathrm{OH}]\right)(\mathrm{e})$, ozone production rate $\left(\mathrm{P}\left(\mathrm{O}_{3}\right)\right)$ from the reaction of $\mathrm{HO}_{2}$ with $\mathrm{NO}$ that is equivalent to the $\mathrm{OH}$ recycling rate (f). Gaps in the time series (a-f) indicate missing data. 


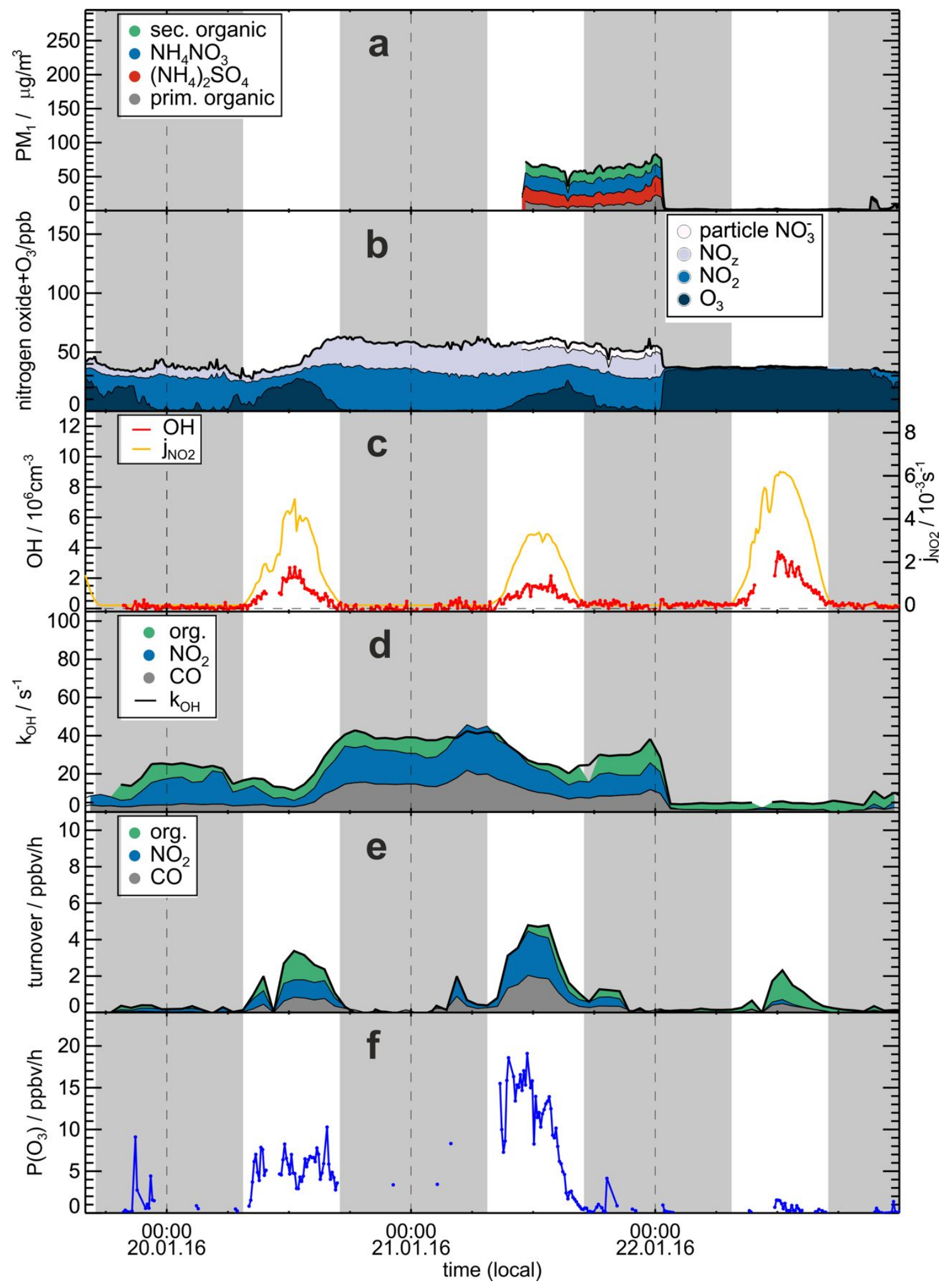

Figure S7. Same as Figure S6 but for the haze event from January $19^{\text {th }}$ to January $22^{\text {nd }}$ 2016. 


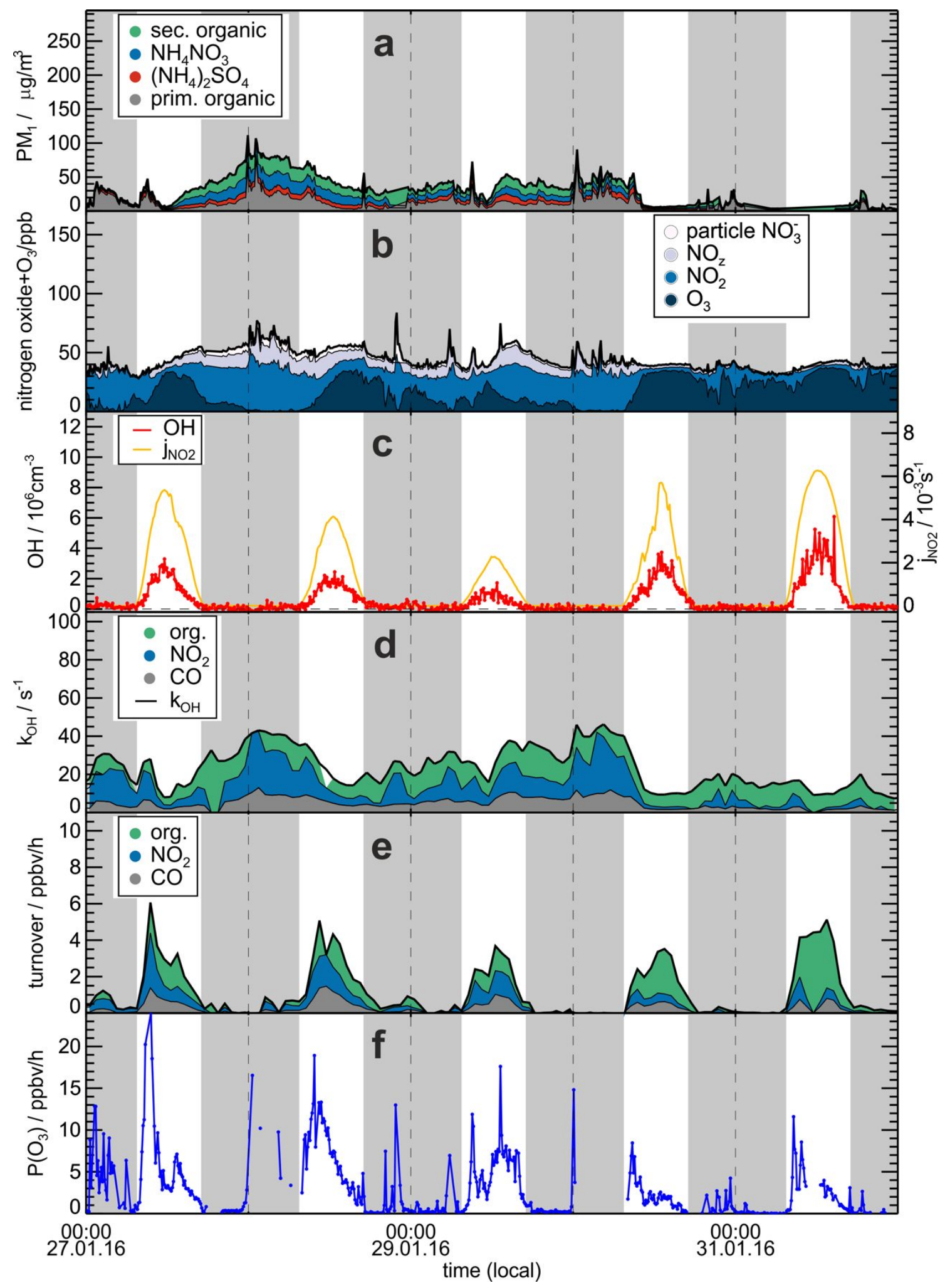

Figure S8. Same as Figure S6 but for the haze event from January $27^{\text {th }}$ to January $31^{\text {st }}$ 2016. 


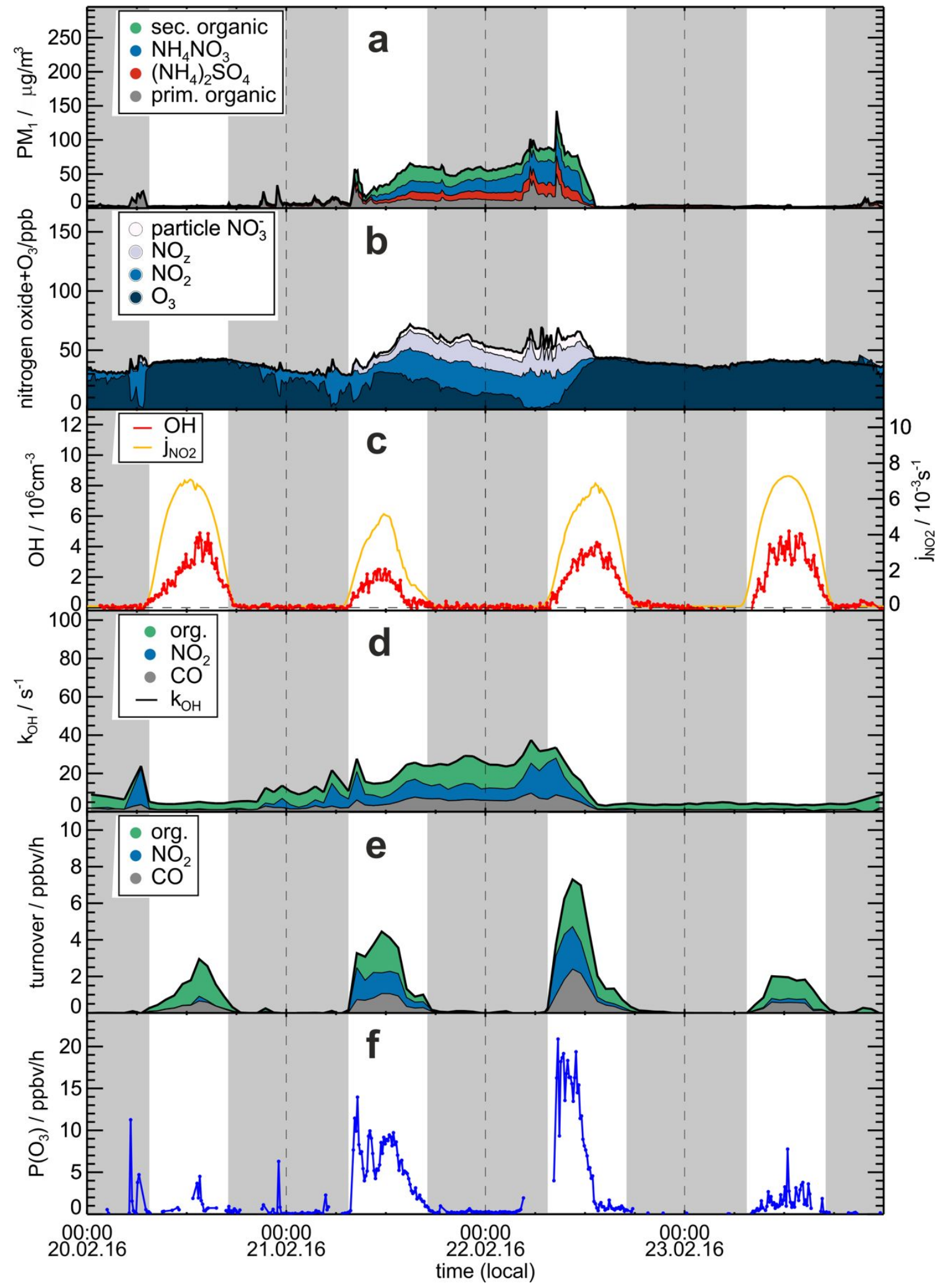

Figure S9. Same as Figure S6 but for the haze event from February $20^{\text {th }}$ to February $23^{\text {rd }} 2016$. 


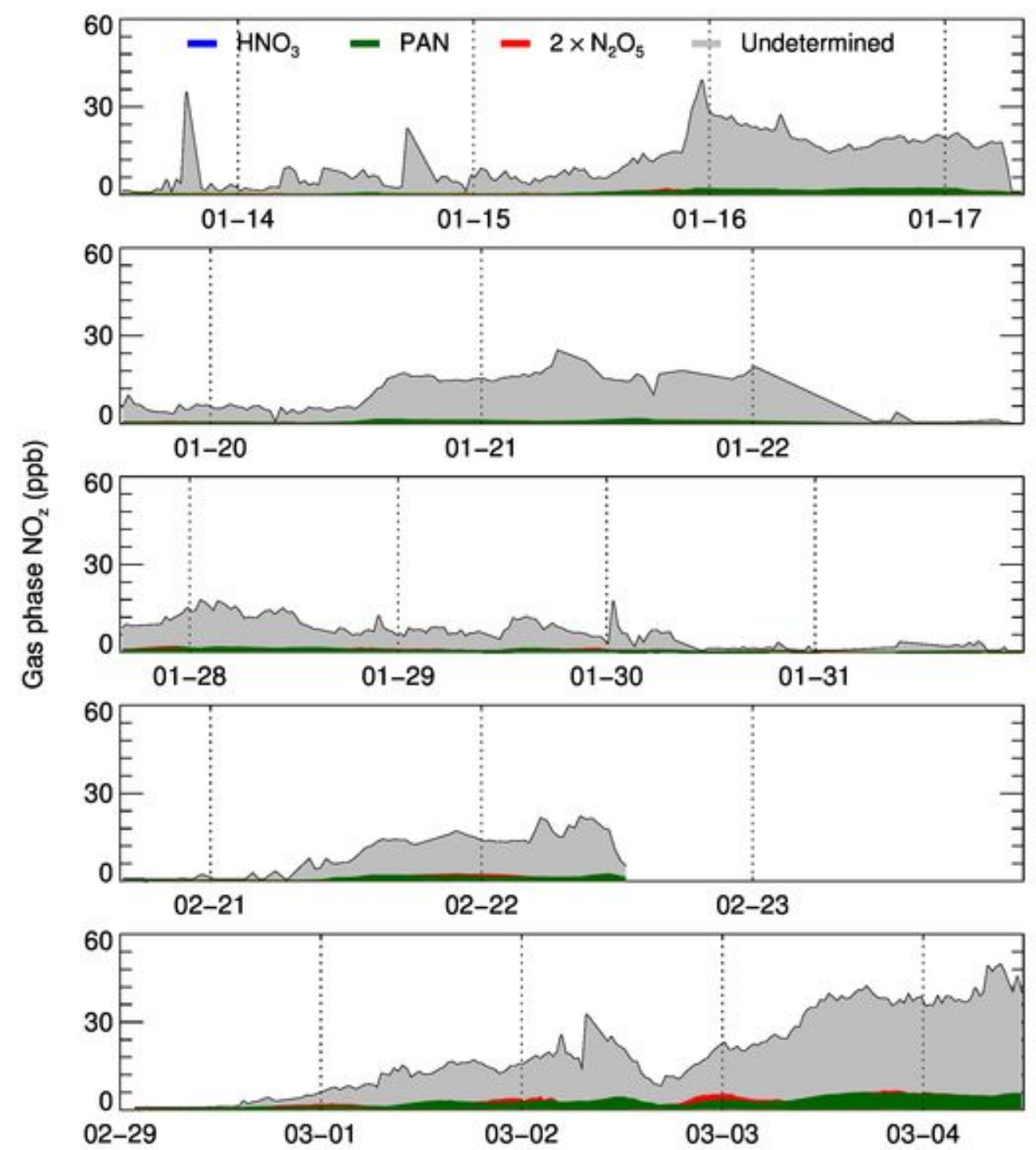

Figure S10. The comparison of the experimentally determined gas phase oxidized nitrogen compounds $-\mathrm{NOz}\left(=\mathrm{NOy}-\mathrm{NOx}-\mathrm{NO}_{3}{ }^{-}\right)$with the detailed measurements of $\mathrm{NOz}$ such as PAN, $\mathrm{N}_{2} \mathrm{O}_{5}$ and $\mathrm{HNO}_{3}$ for the analyzed five haze events experienced during this campaign. 

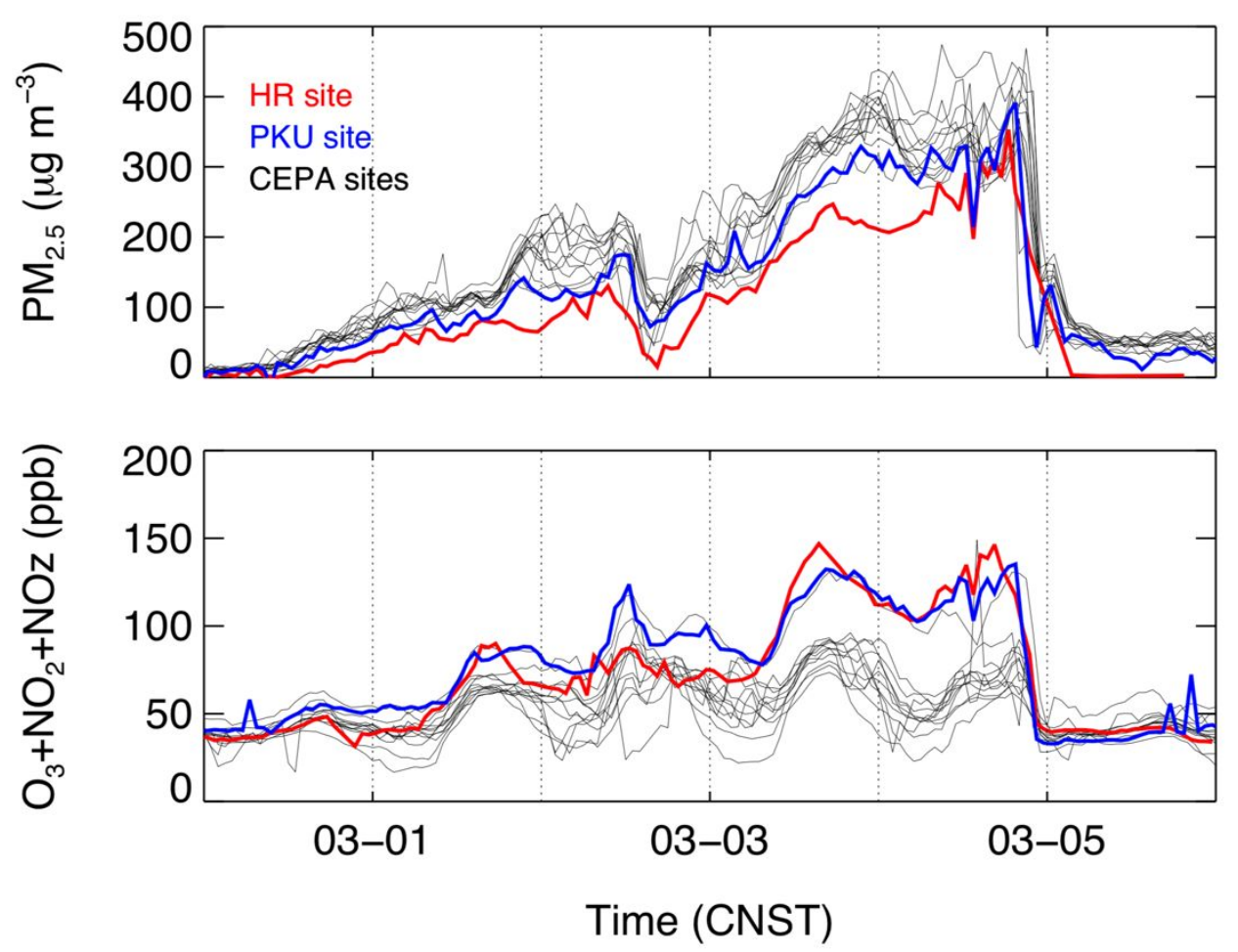

Figure S11. Upper panel: Observed $\mathrm{PM}_{2.5}$ and total oxidant concentrations as characterized by the regional monitoring network and observed $\mathrm{PM}_{2.5}$ concentrations at $\mathrm{HR}$ site, PKU site and the CEPA sites in Beijing. Lowe panel: Observed $\mathrm{O}_{3}+\mathrm{NO}_{2}+\mathrm{NOz}$ concentrations at $\mathrm{HR}$ site and PKU site and the $\mathrm{O}_{3}+\mathrm{NO}_{2} *\left(\mathrm{NO}_{2} *=\mathrm{NO}_{2}+\right.$ interferences from $\mathrm{NOz}$ compounds) concentrations at the CEPA sites. The $\mathrm{NO}_{2}$ observations at CEPA sites are performed by chemiluminescence instruments using a Mo-converter which is known to have significant interference from NOz (e.g., Dunlea et al., 2007). Therefore, $\mathrm{O}_{3}+\mathrm{NO}_{2} *$ measurements at the CEPA sites are compared to the $\mathrm{O}_{3}+\mathrm{NO}_{2}+\mathrm{Noz}$ concentrations at $\mathrm{HR}$. 


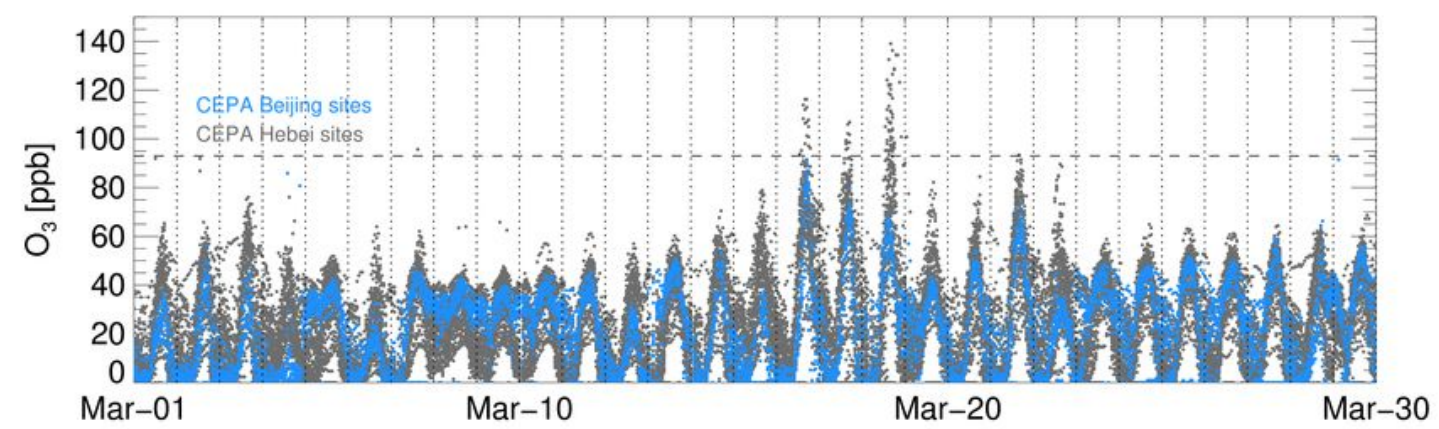

Figure S12. The observed $\mathrm{O}_{3}$ concentrations from the CEPA sites in both Beijing and Hebei in March 2016. The dashed line marks the $1 \mathrm{hr}$ Air Quality Standard for $\mathrm{O}_{3}$ in China.

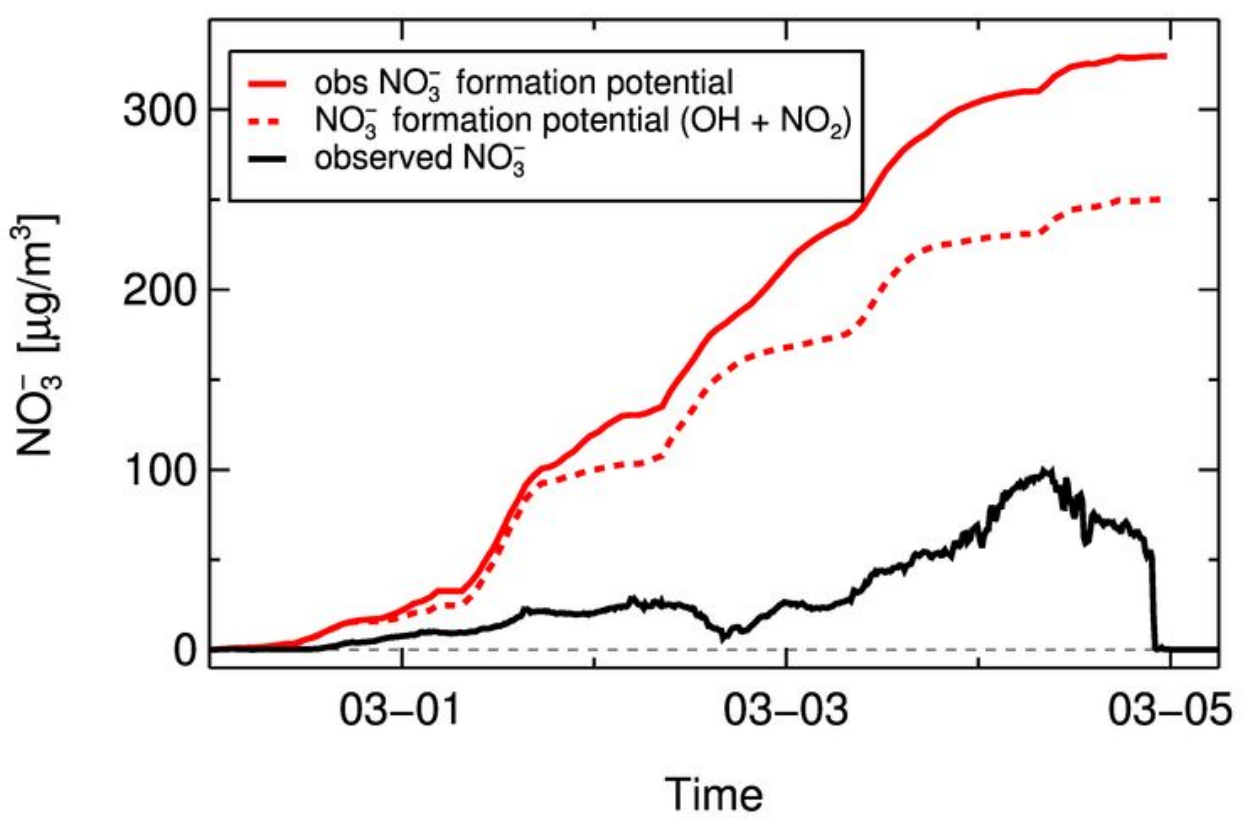

Figure S13. The observed $\mathrm{PM}_{1}$ particulate nitrate $\left(\mathrm{NO}_{3}^{-}\right)$concentrations by AMS and the experimentally determined $\mathrm{NO}_{3}{ }^{-}$formation potential (accumulated production since Feb $29^{\text {th }}$ ) according to Eq. 2 of the main text. The dashed line denotes the experimentally determined $\mathrm{NO}_{3}{ }^{-}$formation potential from the reaction between $\mathrm{OH}$ and $\mathrm{NO}_{2}$. 


\section{References}

Clegg, S. L., Brimblecombe, P., Wexler, A. S., Thermodynamic model of the system $\mathrm{H}^{+}-\mathrm{NH}_{4}{ }^{+}-\mathrm{SO}_{4}{ }^{2-}-\mathrm{NO}_{3}{ }^{-}-\mathrm{H}_{2} \mathrm{O}$ at tropospheric temperatures. J. Phys. Chem. A. 102, $2137-$ 2154 (1998).

DeCarlo, P. F., et al., Field-deployable, high-resolution, time-of-flight aerosol mass spectrometer. Anal. Chem. 78, 8281-8289 (2006).

Dong, H. B., et al., Technical Note: The application of an improved gas and aerosol collector for ambient air pollutants in China. Atmos. Chem. Phys. 12, 10519-10533 (2012).

Dunlea, E. J., et al., Evaluation of nitrogen dioxide chemiluminescence monitors in a polluted urban environment. Atmos. Chem. Phys. 7, 2691-2704 (2007).

Feiner, P. A., et al., Testing Atmospheric Oxidation in an Alabama Forest. J. Atmos. Sci. 73, 4699-4710 (2016).

Fuchs, H., et al., Detection of $\mathrm{HO}_{2}$ by laser-induced fluorescence: calibration and interferences from $\mathrm{RO}_{2}$ radicals. Atmos. Meas. Tech. 4, 1209-1225 (2011).

Fuchs, H., et al., Investigation of potential interferences in the detection of atmospheric ROx radicals by laser-induced fluorescence under dark conditions. Atmos. Meas. Tech. 9, 1431-1447 (2016).

Fuchs, H., et al., Comparison of $\mathrm{OH}$ reactivity measurements in the atmospheric simulation chamber SAPHIR. Atmos. Meas. Tech. 10, 4023-4053 (2017a).

Fuchs, H., et al., OH reactivity at a rural site (Wangdu) in the North China Plain: contributions from $\mathrm{OH}$ reactants and experimental $\mathrm{OH}$ budget. Atmos. Chem. Phys. 17, 645-661 (2017b).

Hofzumahaus, A., et al., Amplified Trace Gas Removal in the Troposphere. Science 324, 1702-1704 (2009).

Huang, W., Chen, Z. Q., Hua, D. Z., Zeng, L. M., Ye, H. J., Development and application of online monitoring technology for atmospheric peroxyacetyl nitrate. Environmental Pollution \& Control 39, 1033-1038 (2017).

Jayne, J. T., et al., Development of an aerosol mass spectrometer for size and composition analysis of submicron particles. Aerosol. Sci. Tech. 33, 49-70 (2000).

Jimenez, J. L., et al., Ambient aerosol sampling using the Aerodyne Aerosol Mass Spectrometer. J. Geophys. Res-Atmos. 108, 1-13 (2003).

Li, L. J., Hoffmann, M. R., Colussi, A. J., Role of Nitrogen Dioxide in the Production of Sulfate during Chinese Haze-Aerosol Episodes. Environ. Sci. Technol. 52, 2686-2693 (2018).

Li, X., et al., Exploring the atmospheric chemistry of nitrous acid (HONO) at a rural site in Southern China. Atmos. Chem. Phys. 12, 1497-1513 (2012).

Li, X., et al., Missing Gas-Phase Source of HONO Inferred from Zeppelin Measurements in the Troposphere. Science 344, 292-296 (2014).

Liu, P., Ziemann, P. J., Kittelson, D. B., Mcmurry, P. H., Generating Particle Beams of Controlled Dimensions and Divergence .1. Theory of Particle Motion in Aerodynamic Lenses and Nozzle Expansions. Aerosol. Sci. Tech. 22, 293-313 (1995). 
Liu, Y. H., et al., In situ monitoring of atmospheric nitrous acid based on multipumping flow system and liquid waveguide capillary cell. J. Environ. Sci-China. 43, 273-284 (2016).

Lou, S., et al., Atmospheric OH reactivities in the Pearl River Delta - China in summer 2006: measurement and model results. Atmos. Chem. Phys. 10, 11243-11260 (2010).

Mao, J., et al., Insights into hydroxyl measurements and atmospheric oxidation in a California forest. Atmos. Chem. Phys. 12, 8009-8020 (2012).

Middlebrook, A. M., Bahreini, R., Jimenez, J. L., Canagaratna, M. R., Evaluation of Composition-Dependent Collection Efficiencies for the Aerodyne Aerosol Mass Spectrometer using Field Data. Aerosol. Sci. Tech. 46, 258-271 (2012).

Tan, Z. F., et al., Wintertime photochemistry in Beijing: Observations of ROx radical concentrations in the North China Plain during the BEST-ONE campaign. Atmos. Chem. Phys. 18, 12391-12411 (2018).

Tan, Z. F., et al., Radical chemistry at a rural site (Wangdu) in the North China Plain: observation and model calculations of $\mathrm{OH}, \mathrm{HO}_{2}$ and $\mathrm{RO}_{2}$ radicals. Atmos. Chem. Phys. 17, 663-690 (2017).

Wang, H. C., Chen, J., Lu, K. D., Development of a portable cavity-enhanced absorption spectrometer for the measurement of ambient $\mathrm{NO}_{3}$ and $\mathrm{N}_{2} \mathrm{O}_{5}$ : experimental setup, lab characterizations, and field applications in a polluted urban environment. Atmos. Meas. Tech. 10, 1465-1479 (2017a).

Wang, $\mathrm{H}$. C., et al., High $\mathrm{N}_{2} \mathrm{O}_{5}$ Concentrations Observed in Urban Beijing: Implications of a Large Nitrate Formation Pathway. Environ. Sci. Tech. Let. 4, 416-420 (2017b).

Yuan, B., et al., Measurements of ambient hydrocarbons and carbonyls in the Pearl River Delta (PRD), China. Atmos. Res. 116, 93-104 (2012). 